\title{
A SZABADIDŐS SPORT KERESLETI ÉS KÍNÁLATI ELEMEK VIZSGÁLATA AZ ÉSZAK-ALFÖLDI RÉGIÓ EGÉSZSÉGTURIZMUSÁBAN
}

\section{Szerzők:}

Lenténé Puskás Andrea $(\mathrm{PhD})$

Debreceni Egyetem (Magyarország)

Hidvégi Péter $(\mathrm{PhD})$

Debreceni Egyetem (Magyarország)

Pucsok József Márton (PhD)

Debreceni Egyetem (Magyarország)

Dobay Beáta (PhD, PaeDr.)

Selye János Egyetem (Szlovakia)

Molnár Anikó

Debreceni Egyetem (Magyarország)

Bíró Melinda (PhD)

Debreceni Egyetem (Magyarország)

Első szerző e-mail címe:

lpandrea@sport.unideb.hu

\section{Lektorok:}

\author{
Müller Anetta (PhD, habil.) \\ Debreceni Egyetem (Magyarország) \\ Bácsné Bába Éva (PhD, Prof.) \\ Debreceni Egyetem (Magyarország)
}

Lenténé Puskás Andrea, Hídvégi Péter, Pucsok József Márton, Dobay Beáta, Molnár Anikó és Bíró Melinda (2019): A szabadidős sport keresleti és kínálati elemek vizsgálata az Észak-alföldi régió egészségturizmusában. Különleges Bánásmód, 5. (4). 45-54. DOI 10.18458/KB.2019.4.45

\section{Absztrakt}

Napjainkban a szabadidős és rekreációs trendek ez egészségtudatos fogyasztók markáns megjelenését igazolják, akik körében a különböző szabadidôs sport, fitnesz szolgáltatások iránti igény az üdülésük alatt is megfogalmazódik, melyhez a szállodák kínálata is alkalmazkodik. Kutatásunk az Észak-alföldi régió szállodáinak $(n=39)$ szabadidős sportkínálatának vizsgálatára és a szállodába érkező vendégek $(n=141)$ szabadidős sport és fitnesz kínálat iránti keresletének alakulására irányult. Kutatásunk eredménye azt igazolta, hogy a szálláshely választásban a vendégek 23,4\%-át befolyásolja a szálloda kínálatában megjelenő rekreációs lehetőségek és 19,1\%-át pedig a sportolási lehetőségek megléte. A megkérdezettek 62,4\%-nak fontos, hogy az üdülés ideje alatt is legyen lehetôségük szabadidôs tevékenységre, és ezt 70,2\%-uk igénybe is veszi az üdülés alatt. Népszerűnek bizonyultak a zenés-táncos mozgásformák, természetben úzhető 
sportok (kerékpár, túra) és a fitnesztermi kínálati elemek. A nők és férfiak preferenciarendszere eltért, szignifikáns eltérést tudtunk kimutatni: amíg a nők inkább a jógát, a kondicionáló termi futópadot, addig a férfiak a szabadsúlyok használatát részesítették inkább előnyben.

Kulcsszavak: szabadidős sport, fitnesz, turizmus

Diszciplina: turizmus, egészségtudomány,

\begin{abstract}
Nowadays, leisure and recreational trends justify the significant appearance of health-conscious consumers, among whom the need for various recreational sports and fitness services is formulated during their holiday, to which the hotels offerings are adapted. The aim of our research was to analyse leisure sports offerings of hotels in the Northern Great Plain region $(n=39)$ and the development of hotel guests $(n=$ 141) demand for leisure sports and fitness services. The results of our research confirmed, that $23.4 \%$ of the guests are influenced by the recreational- and $19.1 \%$ by the sports elements of the hotels offerings. $62.4 \%$ of those surveyed find it important to have the possibility for leisure activities during their stay, and $70.2 \%$ of them use these services during their stay. Music and dance forms of exercise, outdoor sports (cycling, hiking), and fitness room services have proven to be the most popular. The preference system of males and females differed, in which we could identify a significant difference: while females preferred yoga and the conditioning treadmill, males preferred the use of free weights.
\end{abstract}

Keywords: leisure sports, fitness, tourism

Disciplines: tourism, health sciences

A szabadidôs és turisztikai trendekben az élménykeresés, a növekvő egészségtudatosság, a preventív szemlélet és az aktív tevékenységek szerepe növekszik, mely több hazai és nemzetközi kutatásban is megjelenik (Dávid 2002; Michalkó 2003; Gibson 2003; Bánhidi-Leber 2007).

Igaz, hogy a szabadidôs tevékenységek között a hazai lakosság különböző célcsoportjában végzett szabadidős kutatások tanúságai szerint, még mindig a passzív tevékenységek ( $t v$ nézés, zenehallgatás, olvasás stb.) dominálnak, azonban ezek mellett egyre inkább megjelenik a szabadidősport is (Hunyadi 2005; Murányi 2010; Kovács 2011; Müller és társai, 2011; Major 2014; Boda és társai, 2015; Kovács 2015; Laoues és társai, 2019a; Mező és társai, 2019). A passzív szabadidős tevékenységek mellett az egészségtudatos magatartás terjedésével lassan növekszik a szabadidős sportot űzők száma is Magyarországon.

A szabadidősport területét a sport és fitnesz trendjei erőteljesen meghatározzák (Gödény és társai, 2018; Müller és társai, 2017). Több kutatás igazolja, hogy nem csak a szabadidőben, de az üdülés alatt is egyre fontosabb a turistáknak, hogy szabadidejüket az egészségmegőrzéssel kapcsolatos wellness, gyógy és szabadidős sport szolgáltatásokkal töltsék (Müller-Szabó 2009; Mosonyi és társai, 2013; Csirmaz-Pető 2015; Smith és Puczkó 2010; Michalkó és társai, 2011; Kerényi és társai, 2009; Sőrés és társai, 2012; Müller és társai, 2016; LöveiKalmár 2017; Darabos-Nagy 2018; Müller és társai, 2009, Fenyves és társai, 2019). 
Az Észak-alföldi régió egyik legversenyképesebb turisztikai terméke az egészségturizmus (MüllerKönyves, 2006), mely a régió igen sok településén jelen van, ezért kutatásunk fókuszába ezt a régiót helyeztük. Korábbi kutatásaink igazolták, hogy a régió turisztikai kínálatában a wellness, sportkínálat megjelenik, hiszen a turisták igénylik az üdülésük alatt a szabadidő aktív és hasznos eltöltésének lehetőségét, így ez a szolgáltatóknak a versenyképességük egyik meghatározó eleme (Lenténé és társai, 2018; Hidvégi és társai, 2019; Lenténé és társai, 2019a;b;c; Fenyves és társai, 2014).

\section{MÓDSZER}

Vizsgálatunk során az Észak-alföldi régió szállodáinak szabadidős sportkínálatának vizsgálatára és a szállodába érkezô vendégek szabadidős sport és fitnesz kínálat iránti keresletének alakulására fókuszáltunk. Célunk volt ezen kínálati elemek megjelenését összevetni a keresleti oldalról megjelenő igényekkel.

\section{Minta}

A kutatás során 39 szállodában vizsgáltuk a szabadidősport kínálati elemek megjelenését kérdőív segítségével. A keresleti oldal véleményének feltárása érdekében 141 olyan vendéget kérdeztünk meg, akik a vizsgált szállodákba érkeztek. Az Észak-alföldi régió szállodáiban végeztünk kérdőíves felmérést a sport és rekreációs szolgáltatásokkal kapcsolatos igényeikre, véleményekre fókuszálva, majd ezeket összevetettük a régió szállodáinak kínálatában szolgáltatásokkal. A keresleti oldalról a mintában 141 fó kerül lekérdezésre. A válaszadók 45,4\%-a férfi, míg 54,6\%-a nő volt. A vendégek életkori megoszlása azt mutatta, hogy a férfiak között a 18-35 év közötti korosztály képviseltette magát magasabb arányban $(53,7 \%)$, míg a nôknél a válaszadók több, mint fele (61,8\%) a 35 év fölötti korosztályhoz tartozott.

\section{Eszközök}

Korábbi kutatásunk során kérdőíves vizsgálatot végeztünk az Észak-alföldi régióban megtalálható szállodák körében, amelynek során arra kerestük a választ, hogy milyen egészségmegőrzést szolgáló rekreációs és sportszolgáltatásokat nyújtanak a vendégek számára. A kérdőívek 45 szállodába kerültek kiküldésre, amelyek közül 39 volt, aki válaszolt a kérdésekre. A kérdőívben több kérdéscsoportban kérdeztünk rá a szállodák kínálatában megjelenő szolgáltatásokra, azonban jelen tanulmányban csak a szabadidős sportolási lehetőségek, keleti vagy aerobik jellegú mozgásprogramok és egyéb sportszolgáltatások azok a területek, amelyeket elemzésre kerültek.

A keresleti oldalnak a szállodák sport és rekreációs szolgáltatásaival, kínálati elemeivel kapcsolatos véleményét szintén egy általunk összeállított kérdőív segítségével kívántuk feltérképezni.

\section{Eljárás}

Először a szállodák szolgáltatási elemeinek feltárására állítottuk össze a kérdőívet. A lekérdezést, adatfeldolgozást és elemzést követően a keresleti oldal véleményének feltárásához állítottuk össze hasonló kérdéscsoportokat tartalmazó mérô eszközt. A keresleti oldal elemzése ezt követően kezdődött el. Az eredmények ismeretében összehasonlítottuk a vendégek által megfogalmazott, és a kínálati oldalon megjelenő szolgáltatásokat.

Mindkét kérdőív adatainak feldolgozása SPSS statisztikai program segítségével történt, számítottunk átlagot, szórást, az összefüggések vizsgálatára pedig chi2 próbát alkalmaztunk. 


\section{EREDMÉNYEK}

\section{Keresleti oldal vizsgálata}

A megkérdezettek 41,8\%-a évente egy alkalommal, 51,8\%-a pedig évente 2-5 alkalommal megy szállodába üdülni. Minimális (5\%) volt azoknak az aránya, akik akár 6-nál több alkalommal üdülési céllal ellátogatnak egy szállodába. Ezekből a válaszokból jól körvonalazódik az a fajta utazási trend, miszerint a többször utazunk rövidebb időre, azaz a hosszú hétvégés utazások kereslete nő. A válaszadók többsége (39,7\%) a négy csillagos, 17\%-a a legmagasabb besorolású, öt csillagos szállodát választják kikapcsolódásuk helyszínéül, míg 13,5\% a három csillagos szállodákat részesítik előnyben. A megkérdezettek közel harmada $(29,8 \%)$ válaszolta azt, hogy nekik mindegy, hogy milyen besorolású szállodában tölti el a pihenésre, kikapcsolódásra szánt idôt. A szállodai pihenés az eredmények alapján úgy tủnik, hogy jellemzően a nyári időszakra $(64,5 \%)$ és ezen belül is inkább a hétvégékre koncentrálódik (43,3\%), a többség ilyenkor üdül. $\mathrm{Az}$ üdülésre fordított napok számát vizsgálva azt találtuk, hogy a 3 napos (36,2\%), 5 napos (20,5\%) és 7 napos $(11,3 \%)$ üdülések fordulnak elő magasabb arányban.

A rekreációs trendek azt mutatják, hogy napjaink egészségtudatos fogyasztóinak fontos a rendszeres testmozgás, melyet üdülésük alatt is szeretnének végezni (Müller-Bácsné, 2018). Az egészségtudatos magatartás nem csak a rekreációban (Juhász és társai, 2015) de a turizmusban is egyre erôsödik (Lengyel 2015; 2016). Azok az emberek, akik számára az egészség fontos értékként jelenik meg, azok az üdülésük alatt is igénylik és igénybe is veszik a különböző egészségmegőrző (sport, wellness, fitnesz, stb.) szolgáltatásokat (Lenténé és társai, 2019). Ezért kíváncsiak voltunk arra, hogy az általunk vizsgált régióba ellátogató vendégeket a szálloda választásánál mennyiben befolyásolják a rekreációs és sportolási lehetőségek. Azt találtuk, hogy a válaszadók 23,4\%-nak szálloda választását befolyásolják a szálloda kínálatában megjelenő rekreációs lehetôségek, 19,1\%-nál pedig a sportolási lehetőségek. A megkérdezettek 62,4\%-nak fontos, hogy az üdülés ideje alatt legyen lehetőségük valamilyen rekreációs tevékenységre, és ezt 70,2\% igénybe is veszi. Emiatt magas volt azoknak az aránya, akik igénylik és fontosnak tartják azt, hogy az általuk választott szállodában legyenek igénybe vehető sporteszközök és ezeket igénybe is veszik $(68,8 \%)$.

Úgy túnik, hogy közel azonos arányban vannak azok, akik számára fontos, illetve nem fontos, hogy rendelkezzen a szálloda fitneszteremmel. A szállodai fitnesztermet a vendégek 51,8\%-a veszi igénybe az üdülési idő alatt törekedve a szabadidő aktív eltöltésére és az egészség megőrzésére, melyet több kutatás is megerősít (Müller-Szabó 2009; Lenténé és társai, 2018). Érdekes eredmény, hogy a fitnesztermet leginkább a női vendégek igénylik és veszik igénybe $(55,8 \%)$. A vendégek több, mint fele számára az is fontos, hogy milyen felszereltséggel rendelkezik a szálloda fitneszterme $(58,2 \%)$, közülük is inkábba nók számára (59,7\%), kevesebben voltak azok, akik úgy nyilatkoztak, hogy ez számukra nem fontos tényező $(41,8 \%)$.

A szállodákban található fitnesztermek mérete is nagymértékben befolyásolhatja a benne található gépek számát és fajtáját. Az eredmények alapján megállapítható, hogy a vendégek egyaránt igénylik a kardio gépeket - elsősorban a futópadot - és az izotóniás erősítő gépeket is (1. táblázat). A kérdôívet kitöltők jelentős többsége $(71,6 \%)$ nem igényli azt, hogy a szálloda fitnesz termében szakképzett edző segítse a munkáját, mindösszesen a megkérdezettek 28,4\%-a válaszolta azt, hogy igényelné egy szakember jelenlétét. Mint tudjuk, nem mindenki a fitneszteremben az egyénileg végezhetô sportolási formákat részesíti előnyben, sokkal inkább preferálja azokat a mozgásformákat, amelyeket csoportosan lehet végezni. Éppen ezért arra is kíváncsiak voltunk, hogy a csoportos zenés 
KÜLÖNLEGES BÁNÁSMÓD, V. ÉVF. 2019/4.

órákra, keleti vagy aerobic jellegú mozgásprogramokra, valamint egyéb szabadidő sportokra mekkora igény van egy üdülési időszak alatt. A vendégek 48,9\%-a számára fontos, hogy legyen ilyen típusú mozgásokra lehetőség, ugyanakkor 51,1\% számára ez nem fontos tényező. Azon vendégek, akik szeretik az ilyen típusú mozgásformákat az alábbi táblázatban feltüntetett mozgásformákat részesítik előnyben (2. táblázat).
Ezen mozgásformák közül csak a jóga esetében tudtunk szignifikáns különbséget kimutatni a nemek között vélhetően annak köszönhetően, hogy a jóga szervezetre és egészségre gyakorolt hatását kutatók is igazolták (Bodolai és társai, 2016). A jógázni vágyók között jelentősen magasabb arányban voltak a nők $(33,8 \%)$, mint a férfiak $(9,4 \%)$.

1. táblázat. Fitnesztermek felszereltségére vonatkozó igények. (Forrás: Saját vizsgálatok, 2019)

\begin{tabular}{|l|r|r|r|r|}
\hline \multicolumn{1}{|c|}{ Fitnesz eszközök } & Létszám (\%) & \multicolumn{1}{|c|}{ Férfiak (\%) } & \multicolumn{1}{c|}{ Nök (\%) } & Szig. \\
\hline Ellipszis tréner & 15,6 & 12,5 & 18,2 &, 245 \\
\hline Futópad & 46,8 & $\mathbf{3 1 , 3}$ & $\mathbf{5 9 , 7}$ &, $\mathbf{0 0 1}$ \\
\hline Taposógép & 14,9 & 9,4 & 19,5 &, 073 \\
\hline Spinning kerékpár & 11,3 & 18,8 & 5,2 &, 012 \\
\hline Izotóniás erôsító gép & 23,4 & 28,1 & 19,5 &, 157 \\
\hline Szabadsúlyok & 23,4 & $\mathbf{3 7 , 5}$ & $\mathbf{1 1 , 7}$ &, $\mathbf{0 0 0}$ \\
\hline Egyéb & 16,3 & $\mathbf{2 8 , 1}$ & $\mathbf{6 , 5}$ &, $\mathbf{0 0 1}$ \\
\hline
\end{tabular}

2. táblázat: Csoportos zenés mozgásformákra vonatkozó igények - nemek. (Forrás: Saját vizsgálatok, 2019)

\begin{tabular}{|l|r|r|r|r|}
\hline \multicolumn{1}{|c|}{$\begin{array}{c}\text { Csoportos zenés mozgás- } \\
\text { formák }\end{array}$} & \multicolumn{1}{c|}{$\begin{array}{c}\text { Létszám } \\
\mathbf{( \% )}\end{array}$} & \multicolumn{1}{c|}{$\begin{array}{c}\text { Férfiak } \\
\mathbf{( \% )}\end{array}$} & \multicolumn{1}{c|}{$\begin{array}{c}\text { Nők } \\
\mathbf{( \% )}\end{array}$} & Szig. \\
\hline Fit-ball & 12,8 & 15,6 & 10,4 &, 250 \\
\hline Pilates & 12,8 & 15.6 & 10,4 &, 250 \\
\hline Kardio tréning & 11,3 & 12,5 & 10,4 &, 447 \\
\hline Jóga & $\mathbf{2 2 , 7}$ & $\mathbf{9 , 4}$ & $\mathbf{3 3 , 8}$ &, $\mathbf{0 0 0}$ \\
\hline Aerobic & 10,6 & 9,4 & 11,7 &, 436 \\
\hline Fitnesz/alakformáló edzés & 15,6 & 9,4 & 20,8 &, 050 \\
\hline Thai Chi & 9,9 & 12,5 & 7,8 &, 258 \\
\hline Zumba & 13,5 & 6,3 & 19,5 &, 018 \\
\hline Vizi aerobic & 11,3 & 6,3 & 15,6 &, 068 \\
\hline Egyéb vízi tréning & 9,2 & 9,4 & 9,1 &, 589 \\
\hline
\end{tabular}

A következő táblázatban feltüntetett eredmények azt tükrözik, hogy a rekreációs tevékenységek közül elsősorban a gyalogtúra és a kerékpár túra vonzó a vendégek számára, szívesen végeznek olyan tevékenységet, amely alatt hosszabb időt tölthetnek a szabadlevegőn, mely hozzájárul az egészségük megőrzéséhez. Ezek a természetben űzhető sportok a testnevelésben (Herpainé és társai, 2018), rekreációban (Bíró-Müller 2017; Laoues és társai, 2019a, b; Boda és társai, 2018) és a turizmusban (Borbély-Müller 2015) is egyre markánsabban megjelennek (3. táblázat). 
KÜLÖNLEGES BÁNÁSMÓD, V.ÉVF. 2019/4.

3. táblázat: Szabadidő sportolási lehetöségekre vonatkozó igények - nemek. (Forrás: Saját viżsgálatok, 2019)

\begin{tabular}{|l|r|r|r|r|}
\hline Szabadidő sportolási lehetóség & Létszám (\%) & Férfiak (\%) & Nők (\%) & Szig. \\
\hline Gyalogtúra & 20,6 & 18,8 & 22,1 &, 392 \\
\hline Kerékpár túra & 19,9 & 21,9 & 18,2 &, 368 \\
\hline Golf/mini golf & 10,6 & 15,6 & 6,5 &, 070 \\
\hline Tenisz & 17,0 & 21,9 & 13,0 &, 121 \\
\hline
\end{tabular}

\section{Kínálati oldal vizsgálata}

A korábban érvényben lévő wellness szállodai rendelet kötelezően elôírta a kondicionáló termek, valamint legalább 4 féle mozgásprogram biztosítását a vendégek számára. Ennek jelentősége abban mutatkozott meg, hogy a testi egészség fejlesztéséhez kapcsolódóan nem szezonális jelleggel, hanem egész évben biztosított kínálati elemként jelent meg a szolgáltatási palettán. Az előírásoknak megfelelően a korábbi jogszabály szerint wellness besorolással rendelkező szállodák versenyképességük megőrzése érdekében fitnesstermet alakítottak ki és olyan sportprogramokat kínáltak, melyek a mai napig a kínálatuk része.

Korábbi vizsgálatunk során feltérképeztük a régióban található szállodákban $(\mathrm{N}=39)$, hogy milyen rekreációs és sportolási lehetőséget kínálnak az aktív kikapcsolódásra vágyó vendégek számára. Az eredmények arra világítottak rá, hogy a szállodák 65\%-a nem rendelkezik saját fitneszteremmel, mindössze 35\%-nál biztosított a vendégek számára ingyenesen igénybe vehetô szállodán belüli testedzés. Ezek a kínálati elemek a korábbi wellness besorolású szállodákban találhatóak meg leginkább. Ez valószínúsíthetően a korábbi rendelet megszűnésével van összefüggésben.

Vizsgáltuk továbbá a szállodákban található fitnesztermek felszereltségét is. Az eredmények azt mutatták, hogy a szállodák 32,5\%-ban elsősorban kardio gépek vannak, a leggyakrabban előforduló futópad mellett az ellipszis tréner, taposógép, spinning kerékpár és a szobakerékpár azok az eszközök, amelyek megtalálhatóak még. Több szálloda fitnesztermében van erőfejlesztő gép is. A kínálati oldalon megjelenő szolgáltatások tehát megfelelnek a vendégek elvárásainak, amelyet jelenlegi vizsgálati eredményeink is alátámasztanak.

A fitneszteremben a szállodák 97,5\%-a nem alkalmaz sportszakembert, tehát a különböző típusú gépeket a vendégek önállóan használhatják. A korábbi rendelet értelmében kötelező volt a wellness szállodáknak testnevelő vagy edzői végzettséggel rendelkező sportszakembert alkalmazni (MüllerKönyves 2006; Müller és társai, 2008). Tekintettel arra, hogy az új rendszer nem írja elô kötelezően a sportszakember foglalkoztatását, ezért a szállodák egyrészt költségcsökkentés miatt nem alkalmaznak szakembert, másrészt pedig azért, mert úgy tűnik, hogy a vendégek nem igénylik a sportszakember jelenlétét (Lenténé és társai, 2018).

A kínálati oldalon megjelenô szabadidős sporttevékenységek biztosításánál fontos szempont hogy szórakoztató, élmény centrikus legyen és figyelembe vegye a különböző célcsoportok elvárásait, azaz széles mozgásrepertoár legyen kialakítva. Ezt vizsgáltuk egy korábbi, a régió megyéiben található szállodák szabadidősport kínálatának felmérése során. Arra voltunk kíváncsiak, hogy a régió szállodái biztosítanak-e a szállodán belül szabadidôs sportolási lehetőséget, keleti vagy aerobic jellegú mozgásprogramot a vendégek számára. Az eredmények azt mutatták, hogy a szállodák 65\%-ban nincs lehetôsége a vendégeknek ilyen típusú mozgásprogramokon részt venni, mindössze a szállodák 35\%-a nyújt ilyen jellegü szabadidős sportszolgáltatások. Az eredmények alapján meg- 
állapítható, hogy a kínálati elemekben megjelenő szabadidősportok között a legnépszerúbbek a jóga, aerobic, kerékpár túra és a vízi tréning voltak (Lenténé és társai, 2018).

A vendégek igényeivel egybecseng az az eredmény, hogy a dinamikusabb, aerobic jellegú mozgások jellemzően nem szerepelnek a kínálati elemek között, ehelyett a természetben űzhető life-time jellegű ciklikus sportok és az élményt nyújtó szabadidős programok a népszerűek (Müller-Rácz 2011; Müller és társai, 2011; Dobay-Bendíková 2014; Müller 2015; Müller és társai, 2019).

\section{Megvitatás}

Kutatásunk eredménye azt igazolta, hogy a vendégek 23,4\%-át befolyásolják a szálláshely választásban a szálloda kínálatában megjelenő rekreációs lehetőségek, 19,1\%-át pedig a sportolási lehetőségek. A megkérdezettek 62,4\%-nak fontos, hogy az üdülés ideje alatt is legyen lehetőségük szabadidős tevékenységre, és ezt 70,2\%-uk igénybe is veszi az üdülés alatt. Népszerúnek bizonyultak a zenés-táncos mozgásformák, természetben űzhető sportok (kerékpár, túra), és a fitnesztermi kínálati elemek. A nők és férfiak preferenciarendszere eltért, szignifikáns eltérést tudtunk kimutatni: amíg a nők inkább a jógát, a kondicionáló termi futópadot, addig a férfiak a szabadsúlyok használatát részesítették inkább előnyben. A gyalogtúra és a kerékpár túra azok a rekreációs tevékenységek, amelyek vonzóak a vendégek számára.

\section{Korlátozások}

A vizsgálat során valamennyi, az Észak-alföldi régióban található 3 csillagos, vagy a fölötti besorolással rendelkező szállodába kiküldtük a kérdőíveket $(n=50)$, azonban csak 39 szálloda küldte vissza a kitöltött kérdőíveket, ami 78\%-os válaszadási hajlandóságot mutatott, így a minta nem reprezentatív.

\section{Konklúzió}

Kutatásunk során arra vállalkoztunk, hogy összehasonlítsuk az Észak-alföldi régió szállodáinak $(n=39)$ szabadidős sportkínálatát és a szállodába érkező vendégek $(n=141)$ szabadidős sport és fitnesz kínálat iránti keresletét.

Az eredmények alapján megállapítható, hogy az Észak-alföldi régióban található szállodákba ellátogató vendégek olyan komplex szolgáltatásokat igényelnek, amelyek hozzájárulnak a szabadidő kulturált, élményekben gazdag eltöltéséhez. A vendégek számára fontos, hogy az üdülés ideje alatt legyen lehetőségük valamilyen rekreációs tevékenységre, az általuk választott szállodában legyenek igénybe vehető sporteszközök, ezért a szállodák ehhez igazodva törekednek a szolgáltatási paletta színesítésére és bővítésére, különösen a természetben zajló life-time jellegû ciklikus sportok, az élményt nyújtó sport és szabadidős programok megjelenítésével.

A publikáció elkészitését az. EFOP-3.6.2.-16-201700003 számú projekt támogatta. A projekt az. Európai Unió támogatásával, az Európai Srociális Alap társfinanszirozásával valósult meg.

\section{IRODALOM}

Banhidi, M., \& Leber, R. (2011). Sport-turizmuskörnyezet osztrák-magyar kontextusban. Sport-tourismenvironment in Hungarian-Austrian context.) Edtwin, Wien/Győr.

Biró, M., \& Müller, A. (2017). Aktív pihenés, rekreáció = Active relaxation, recreation. In Dobos, A., Mika, J. (szerk.) Természeti és kultuirtörténeti értékek. Eger térségében = Natural and cultural heritage in the Eger Region. Eger, Magyarország: Líceum Kiadó, 128-130.

Boda, E., Bácsné, B.É., \& Müller, A. (2018). Motiváció vizsgálata a kalandpark-látogátók körébén. 
International Journal of Engineering and Management Sciences / Müszaki és menedzsment tudományi közlemények 3: 3. 106-126.

Boda, E., Bácsné, B.É., Szabados, Gy., \& Müller, A., (2018). A hazai kalandparkok helye a sportszolgáltatások piacán, egyetemi hallgatók körében végzett kutatás tükrében. Studia Mundi - Economica 5: 3. 34-45.

Boda, E., Honfi, L., Bíró, M., Révész, L., \& Müller, A. (2015): A szabadidő eltöltésének és a rekreációs tevékenységek vizsgálata egri lakosok körében. Acta Academiae Paedagogicae Agriensis Nova Series: sectio sport. 42. 49-62.

Bodolai, M., Lívják, E., Boda, E., \& Bíró, M., (2016). A jóga hatása a szervezetre, szerepe a stresszkezelésben. Acta Academiae Paedagogicae Agriensis Nova Series: sectio sport 43. 51-67.

Borbély, A., \& Müller, A. (2015). Sport és turizmus. Debrecen, Magyarország: Campus Kiadó.

Csirmaz, É., \& Pető, K., (2015). International Trends in Recreational and Wellness Tourism. Procedia economics and finance 32. 755-762.

Darabos, É., \& Nagy, T.O. (2018). Turisztikai célú támogatások szerepe az Észak - Alföldi Régió fejlődésében. International Journal of Engineering and Management Sciences / Müszaki és menedzsment tudományi közlemények 3: 4. 365-376.

Dávid, L. (2002). Aktív turizmus. Debreceni Egyetem, Lifelong Learning Központ, Debrecen.

Dobay, B., \& Bendíkóvá, E. (2014). Športové a rekreačné aktivity $v$ životnom štýle dospelých. Exercitatio Corporis-Motus-Salus, 6 (2) 19-31.

Fenyves, V., Orbán I., Könyves, E., Nagy, A., \& Sándor, F. (2014): Economical aspects of thermal and medical tourism. Apstract - Applied Studies in Agribusiness and Commerce 8 : 4. 77-84.

Fenyves, V., Szabados, Gy., \& Bács, Z. (2019). The Study of motivational factors among participants in a particular pports festival. Sea: Practical Application of Science $7: 1.17-22$.

Gibson, H. J. (2003). Sport tourism: an introduction to the special issue. Journal of Sport Management, 17(3), 205-213.

Gődény, N., Biró, M., Lenténé, P. A., Lente, L., \& Müller, A. (2018). A fogyasztói szokások és trendek változásának vizsgálata a fitnesz területén. In Balogh, L. (szerk.) Fókusz̧ban az egészség. Debrecen, Magyarország: Debreceni Egyetem Sporttudományi Koordinációs Intézet, 9-18.

Herpainé, L. J., Bácsné, B. É., Nagy, Zs., \& Müller, A. (2018). Tantervi lehetőségek a tájékozódás és a turisztika oktatásában. Képzés és gyakorlat: training and practice 16: 1. 73-82.

Hidvégi, P., Biró, M., Lenténé, P. A., Pucsok, J. M., Tatár, A., \& Bárdos, K. (2019). Wellness szolgáltatást igénybevevők felmérése az Észak-alföldi régióban. In Balogh, L. (szerk.) Sokoldalú sporttudomány. Debreceni Egyetem Sporttudományi Koordinációs Intézet, Debrecen. 1-8.

Hunyadi, Z. (2005). Kulturálódási és sqabadidő eltöltési szokások, életmód csoportok. Találkozások a kultúrával 7.

Juhász, I., Kopkáné, P. J., Kiszela, K., Bíró, M., Müller, A., \& Révész, L. (2015). Időskorúak rekreációs fizikai aktivitásának hatása a kardiorespiratorikus rendszerre. Magyar Sporttudományi Szemle 16: 63. 4-8.

Kerényi, E., Müller, A., Szabó, R., \& Mosonyi, A. (2009). Analysis of Agárd, Komárom and Papa’s Thermal and Experiences bath according the guest's satisfaction. In Kerényi, E. (szerk.) Egészségügyi marketing és telekommunikáció. Mátraháza. 56-67.

Kovács, K. (2011). A gyermekek szabadidős tevékenységének alakulása a lakóhely függvényében. Iskolakultura, 11(2-3), 59-67.

Kovács, K. (2015). Pedagógusjelöltek szabadidőeltöltési szokásai és egészségi állapota. Szakmai sqocializáció, 189.

Laoues-, Cz. N., Dobay, B., \& Müller, A. (2019a). Examination of the leisure time-related consumption habits of young people with disabilities with 
special emphasis on sports. Selye E-Studies 10: 2. 34-45.,.

Laoues-Cz., N., Bácsné, B. É., Szerdahelyi, Z., \& Müller, A. (2019b). Sportmotivációs tényezők vizsgálata a 8-18 éves fogyatékossággal élő korosztály körében. Acta Carolus Robertus 9: 1 pp. 121-132.

Lengyel, A. (2015). Extending tourism's role in the tourism - meditation - creativity - innovation sustainability trajectory. In Dunay, Anna (szerk.) Proceedings of the 5 th International Conference on Management 2015. Management, Leadership and Strategy for SMEs' Competitiveness. Gödöllő, Magyarország: Szent István Egyetemi Kiadó. 543-548.

Lengyel, A. (2016). Tourism, meditation, sustainability. Apstract - applied studies in agribusiness and commerce 10: 1. 81-92.

Lenténé, P. A., Biró, M., Dobay, B., \& Pucsok, J. M. (2018): A szabadidő sportolás kínálati elemeinek és szolgáltatásainak vizsgálata Magyarország Észak-alföldi régiójának szállodáiban. SelyeE-Studies 9:1 pp.13-21., 9 p.

Lenténé, P.A., Bíró, M., Hídvégi, P., Molnár, A., Lente, L., \& Pucsok, J. M. (2019c). Analysis of the North Great Plain Region's Accommodation Supply with Special Focus on Sport and Wellness Elements. Geosport for Society 10: 1. 15-24. Paper: /gss.1002-046, $10 \mathrm{p}$.

Lenténé, P.A., Hidvégi, P., Tatár, A., Bíró, M., \& Pucsok, J. M. (2019a). A fürdős és medencés szolgáltatások megjelenése az Észak-alföldi régió szállodáiban In Balogh, L. (szerk.) Sokoldalú sporttudomány. Debrecen, Debreceni Egyetem Sporttudományi Koordinációs Intézet, 54-62., 9 .

Lenténé, P.A., Hidvégi, P., Tatár, A., Pucsok, J.M., \& Biró, M. (2018). Recreational potential of the northern great plain region in Hungary. In Jaromír, Šimonek; Beáta, Dobay (szerk.) Sport science in motion: proceedings from the scientific conference. Športová veda $\mathrm{v}$ pohybe: recenzovaný zborník vedeckých a odborných prác z konferencie. Mozgásban a sporttudomány: válogatott tanulmányok a konferenciáról. Komárno, Szlovákia: Univerzita J. Selyeho, 218-226.

Lenténé, P.A., Tatár, A., Lente, L., Pucsok, J.M., Bíró, M., \& Hidvégi, P. (2019b). A sport és wellness elemek megjelenése az Észak- alföldi régió három-, négy- és ötcsillagos szállodáinak kínálatában. In Bácsné, B. É., Müller, A. (szerk.) "Mozgással az egészségért" A fizikai aktivitás jelentősége a jövő munkavállalóinak egészségmegőrzésében: Nemzetközi Konferencia és Workshop: Válogatott tanulmánykötet. Debrecen, Magyarország: Debreceni Egyetem, 204-215. Lövei-Kalmár K. (2017): A fürdők jelentősége az Észak-Alföldi régió egészségturizmusának fejlesztésében. Köztes Európa. (9) 1-2. 205-213.

Mező, F., Mező, K., \& Mező, K. Sz. (2019). Filmklubok szerepe a mesterséges intelligenciával kapcsolatos attitűdök formálásában. Mesterséges Intelligencia 1: 1. 67-94.

Michalkó, G. (2003). Az aktív turizmus elméleti kérdései. Dávid, L. (szerk.): Aktív turizmus. Debreceni Egyetem, Debrecen.

Michalkó, G., Rátz, T., Irimiás, A. \& Pagini, A. (2011). Az egészségturizmus és az életminőség magyarországi kapcsolatának vonatkozásai, pp. 27-43. In Egészségturizmus és életminöség Magyarországon: Fejezetek az egészség, az utazás és a jól(l)ét magyarországi összefüggéseiröl. (Szerk. Michalkó G. Rátz T.). MTA Földrajztudományi Kutatóintézet., Budapest.

Mosonyi, A., Lengyel, A., \& Müller, A. (2013). Branding potential of spas in the Northern Plain and the Mid-Transdanubian Regions. Apstract Applied Studies in Agribusiness and Commerce. 7: 4-5 97-101.

Murányi, I. (2010). Egyetemisták szabadidős tevékenysége és mentális státusa. Educatio, 19(2), 203-213.

Müller, A. (2015). Fitness Alapismeretek. 8-28p.p. In. Fitness-wellness és táplálkozás terápia elmélete és gyakorlata (szerk. Melczer C.) Pécs, Link: http://www.etk.pte.hu/files/tiny_mce/File/okta 
tas/OktatasiAnyagok/!Palyazati/sport/FitnessW ellness_eK2.pdf

Müller, A., Széles-Kovács, Gy., Seres, J., \& Kristonné Bakos, M. (2011). Főiskolai hallgatók rekreációs tevékenységei. Rekreacio. EU 1:(4.) 3134.

Müller, A., \& Bácsné, B.É. (2018). Az egészséges életmód és a sport kapcsolata. Létavértes, Létavértes SC '97 Egyesület, 96.

Müller, A., Barcsák, B., \& Boda, E. (2016). Health tourism the cavebath of Miskolctapolca. Gy., Juhász, E., Korcsmáros, E., Huszárik (ed.) Korszerû szemlélet a tudományban és az oktatásban. Gazdaságtudományi szekció. 233-245.

Müller, A., Bíró, M., Bodolai, M., Hidvégi, P., Váczi, P., Dávid, L., \& Szántó, Á. (2017). A 2016-os fitnesztrendek helye és szerepe a rekreációban. Acta Academiae Pedagogicae Agriensis Nova Series: Sectio Sport 44. 91-102.

Müller, A., Kerényi, E., \& Könyves, E. (2011). Effect of climate therapy and rehabilitation in Mátra Medical Institute Applied Studies in Agribusiness and Commerce. Apstract - Applied Studies in Agribusiness and Commerce 5: 3-4. 39-42.

Müller, A., \& Könyves, E. (2006). A testnevelő tanárok kapcsolódási pontjai az egészségturizmushoz. Acta Academiae Pedagogicae Agriensis Az Eszterházy Károly Főiskola tudományos közleményei. XXXIII. Kötet. 119-132.

Müller, A. és társai (2008). Új utakon a testnevelő tanárképzés Egerben - A sportszakos hallgatók utazási szokásainak, és a sítáborozás kínálati elemeivel való elégedettségének vizsgálata. Economica. (1.) 85-95.

Müller, A., Könyves, E., Honfi, L., \& Szabó, R. (2009). A hazai barlangok ismertsége és szerepe a turizmusban. Acta Academiae Paedagogicae Agriensis Nova Series: Sectio Sport 35. 37-50.

Müller, A., Lengyel, A., Koroknay, Zs., \& Molnár, A. (2019). Népszerú fitnesz mozgásformák. In Bácsné, B.É., Müller, A. (szerk.) "Mozgással az egészségért" A fizikai aktivitás jelentősége a jövő munkavállalóinak egészségmegőrzésében: Nemzetközi Konferencia és Workshop: Válogatott tanulmánykötet. Debrecen, Debreceni Egyetem. 106-112.

Müller, A., \& Rácz, I. (2011). Aerobic és Fitness irányzatok. Budapest, Pécs Dialóg Campus Kiadó. 277.

Müller, A., \& Szabó, R. (2009). Analysis of Agárd, Komárom and Papa's Thermal bath, According the Guest's satisfaction. Acta Academiae Paedagogicae Agriensis Nova Series: Sectio Sport. 36. 89-101.

Smith, M. \& Puczkó, L. (2010). Egészségturizmus: gyógyászat, wellness, holisztika. Akadémia Kiadó, Budapest.

Sőrés, A., Pető, K., \& Csipkés, M. (2012). Examining life quality in Hajdúszoboszló Tourist Area, with a special focus on health conditions. Agrárinformatika / Journal of Agricultural Informatics 3: 1. 19. 